\title{
Ecological aspects of the Phlebotominae fauna (Diptera: Psychodidae) in the Xakriabá Indigenous Reserve, Brazil
}

\author{
Felipe Dutra Rêgo ${ }^{1 *}$, Paloma Helena Fernandes Shimabukuro ${ }^{1}$, Patrícia Flávia Quaresma ${ }^{1}$, Igor Rismo Coelho², \\ Gabriel Barbosa Tonelli ${ }^{1}$, Kelly Medrado Scofield Silva ${ }^{1}$, Ricardo Andrade Barata ${ }^{3}$, Edelberto Santos Dias ${ }^{1}$ \\ and Célia Maria Ferreira Gontijo'
}

\begin{abstract}
Background: Sand fly collections were performed to study ecological aspects of the Phlebotominae fauna of the Xakriabá Indigenous Reserve, an area with endemic cutaneous leishmaniasis, located in the state of Minas Gerais, Brazil.

Methods: The collections were performed in peridomicile areas and along trails previously selected for the study of wild and synanthropic Leishmania hosts. Differences in the distribution patterns of the sand fly species as well as in species richness and abundance between the different ecotopes were investigated during both rainy and dry seasons over the course of the study period.

Results: A total of 8,046 sand flies belonging to 11 genera and 28 species were collected. Lutzomyia longipalpis and Nyssomyia intermedia were the most abundant species in peridomicile areas, whereas Martinsmyia minasensis and Lutzomyia cavernicola were the most abundant species among the different trail ecotopes.

Conclusion: The different composition of the sand fly fauna observed in the peridomicile areas and in the trails during the study, reinforces the importance of sampled different areas in a phlebotomine fauna survey. The presence of Lutzomyia longipalpis and Ny. Intermedia most abundant in peridomicile can be important to Leishmania infantum and Leishmania braziliensis transmission in the Imbaúbas native village.
\end{abstract}

Keywords: Phlebotominae fauna, Ecological aspects, Minas Gerais State, Nyssomyia, Lutzomyia, Martinsmyia, Leishmania

\section{Background}

Sand flies have been the subject of intense study, primarily in the context of the epidemiology of several diseases, the most notable being leishmaniasis [1]. In addition to Leishmania, sand flies also serve as hosts to bacteria, fungi, certain plasmodium species, haemogregarines, trypanosomes and Endotrypanum [2-6].

Although sand flies are distributed worldwide, they are most abundant in Neotropical regions, where a large number of species can be found [7]. In particular, there

\footnotetext{
* Correspondence: felipedutra@cpqrr.fiocruz.br

'Grupo de Estudos em Leishmanioses, Centro de Pesquisas René Rachou, Fundação Oswaldo Cruz, Av. Augusto de Lima, 1715 Barro Preto, CEP 30190-002 Belo Horizonte, Minas Gerais, Brazil

Full list of author information is available at the end of the article
}

are approximately 900 species of sand flies worldwide, with over 500 in Neotropical regions and about 230 in Brazil $[8,9]$. In the state of Minas Gerais, about 100 species of sandflies have been reported, including important vectors of American Cutaneous Leishmaniasis (ACL) and Visceral Leishmaniasis (VL), such as Bichromomyia flaviscutellata, Lutzomyia longipalpis, Migonemyia migonei, Nyssomyia intermedia and Nyssomyia whitmani [10-14].

Cases of leishmaniasis within indigenous lands in Brazil were first reported in the state of Mato Grosso [15], who reported a large number of ACL cases among the Waurá Amerindians from Alto Xingu. In addition, the epidemiological profiles for VL among the Macuxí and Yanomami in the state of Roraima were described 
[16-18]. More recently, the prevalence of ACL in the Xakriabá Indigenous Reserve (XIR), state of Minas Gerais were reported [19]. Furthermore, the role of sandflies in the transmission cycle of Leishmania within indigenous land has been reported in the Brazilian states of Mato Grosso [20] and Mato Grosso do Sul [21].

Knowledge concerning the Phlebotominae fauna is essential to understanding the transmission of leishmaniasis. Therefore, the aim of this study was to evaluate the ecological parameters of the Phlebotominae fauna - focusing on potential Leishmania vectors - within the XIR, where numerous cases of cutaneous leishmaniasis have been reported.

\section{Methods}

\section{Study area}

The XIR is located in the municipality of São João das

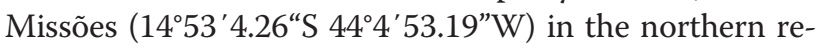
gion of the state of Minas Gerais, Brazil (Figure 1). The indigenous reserve is located in a transition zone between the cerrado and the caatinga biomes and contains native species of both biomes. This study was conducted in the Imbaúbas native village, which had both a high prevalence of human leishmaniasis cases and a number of wild, synanthropic and domestic animal species known to carry Leishmania [22] and was conducted under authorization by FUNAI (National Indian Foundation Protocol Number: 2098/08).

\section{Sand fly collection and environmental characteristics}

Sand flies were captured with HP light traps [23] on three consecutive nights (from $6 \mathrm{pm}$ to $6 \mathrm{am}$ ) for six months between July 2008 and July 2009. A total of 40 traps were installed in 20 randomly selected households in each of the sampled months. (Figure 2A and B).
To collect sand flies from the different ecotopes of the native village, bimonthly systematic samplings were performed between October 2011 and August 2012 on trails previously selected for the study of Leishmania reservoirs [22]. Four trails (330 meters in length each) were selected, and five traps were placed along each trail, totaling $20 \mathrm{HP}$ traps. The traps were set for three full days, for a total of 72 hours of sampling per trap per collection.

Trails 1 and 2 (Figure 2C and D) cut through forest environments with little anthropization characterized as transitional between seasonal deciduous forest and cerrado. Along these two trails, climatic variations throughout the year can abruptly modify soil conditions and vegetation, potentially influencing sand fly abundance and richness. Trail 3 (Figure 2E) was situated on a plateau containing rocky outcrops with numerous craters, favorable for both sand flies and rodents. Trail 3 had a small amount of vegetation with caatinga characteristics. Trail 4 (Figure 2F) was located on the edge of a rocky outcrop plateau that could be characterized as a transitional region between cerrado forest and caatinga vegetation.

\section{Processing of collected sand flies}

Preparation and mounting of the sand flies was performed using Canada balsam for males and Berlese's medium for females [24]. Sand flies were identified to species level using microscopic observation of various internal and external morphological characteristics and using the keys and classification proposed by Galati [8]. The species abbreviations used in the present study follow the proposal by Marcondes [25].

\section{Climate data}

Bioclimatic data, including relative humidity, rainfall and average temperature, were obtained from the National

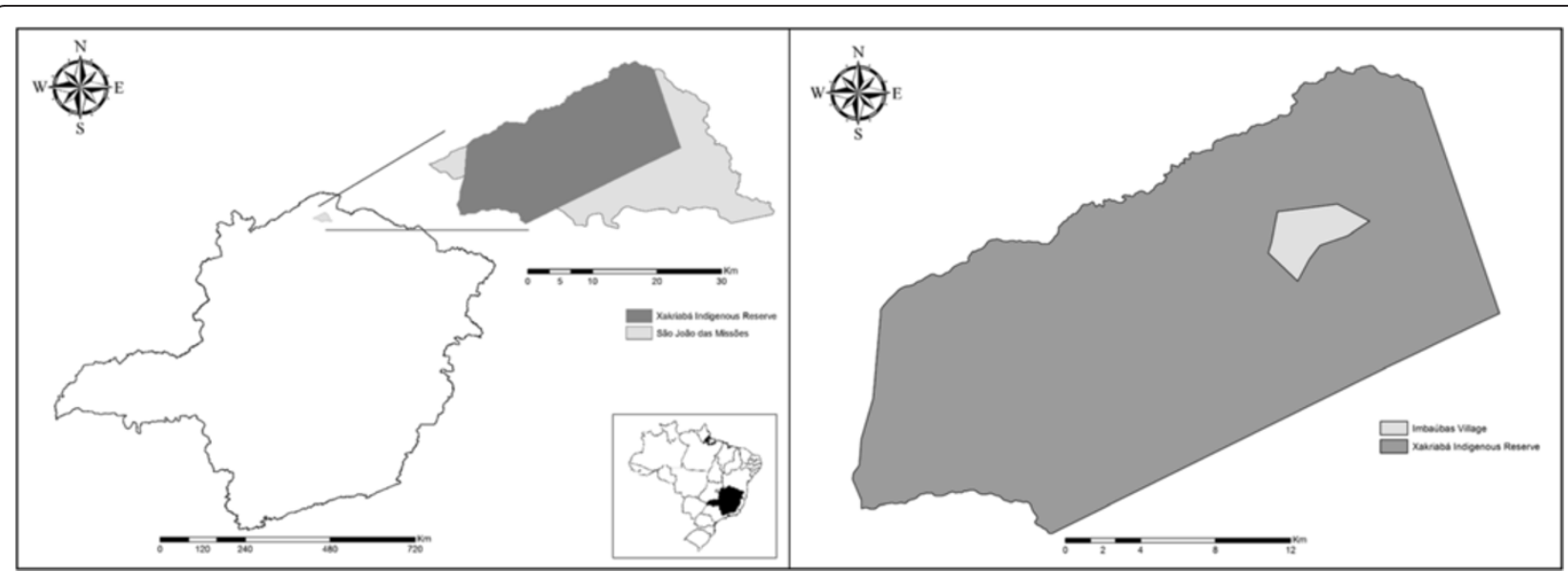

Figure 1 Location of study area. The location of the municipality of São João das Missões in the north of Minas Gerais state, Brazil. The Imbaúbas native village in the Xakriabá Indigenous Reserve, where the study was performed, is indicated. 


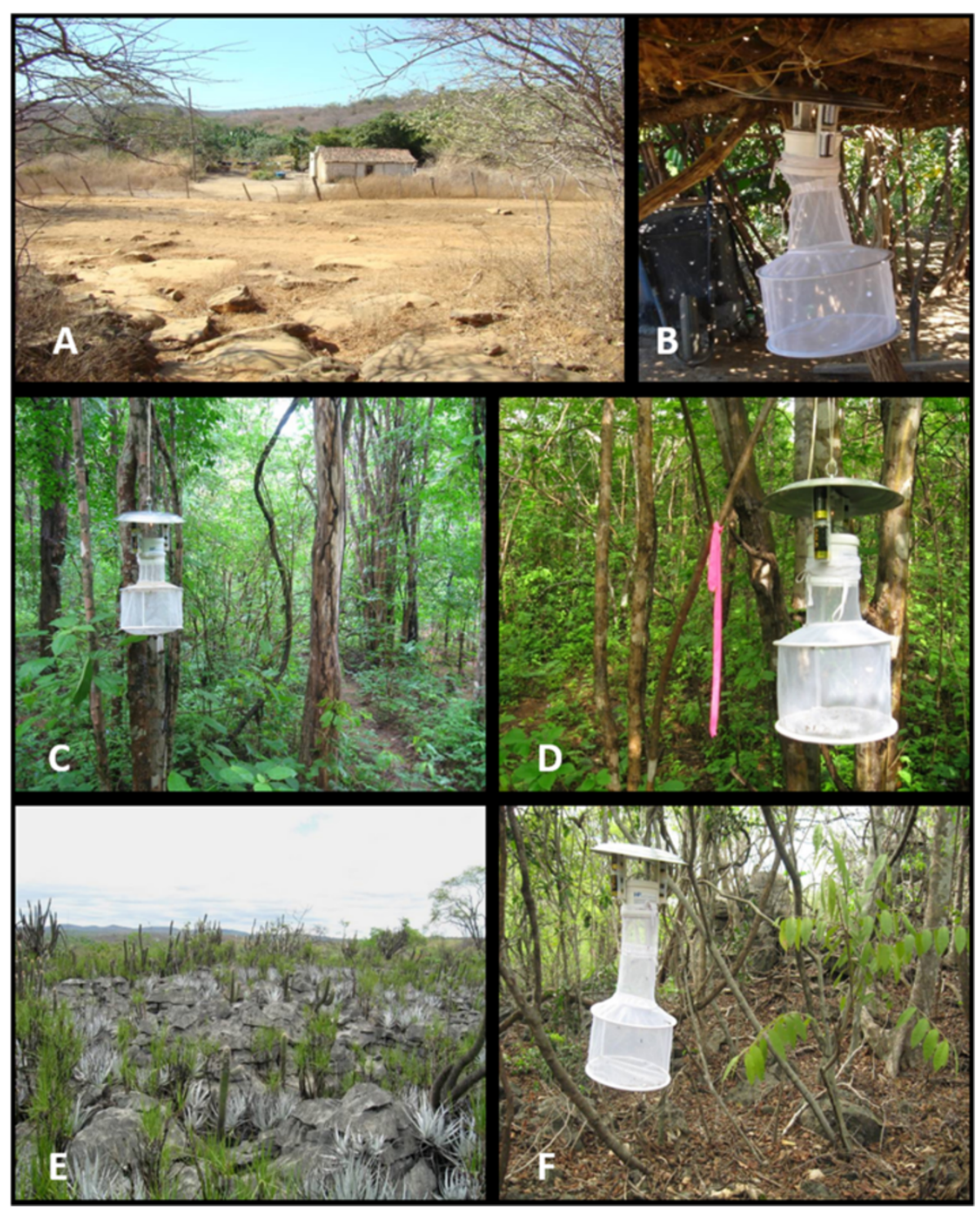

Figure 2 Different ecotopes where the study was performed. A) The peridomicile area of a household in the Imbaúbas native village of the Xakriabá Indigenous Reserve. B) An HP light trap set in the peridomicile area of a household. C, D, E and F) Representative images of trails 1, 2, 3 and 4 , respectively.

Institute of Meteorology for each month of the study period. Data were also collected at the Mocambinho Automatic Weather Station, which is located in the municipality of Itacarambi, state of Minas Gerais, approximately $30 \mathrm{~km}$ from the XIR [26].

Characterization of dry and rainy seasons was performed based on the rainfall of the months in which the captures were performed. During the years in which the peridomicile collections were performed, the dry season included the months of July 2008, September 2008 and July 2009, and the rainy season included November 2008, January 2009 and April 2009. For the collections performed on the trails, the dry season included the months of April 2012, June
2012 and August 2012, and the rainy season included October 2011, December 2011 and February 2012.

\section{Statistical analysis}

Data meeting the prerequisite for normality were subjected to analysis of variance (ANOVA) (KolmogorovSmirnov and Lilliefors test, $\mathrm{p}<0.05)$. Non-parametric data were analyzed using the Kruskal-Wallis test by rank and median. Richness and abundance data were considered as dependent variables, whereas season, month, location and sand fly sex were considered as categorical variables. All analyses were performed using the Statistica 10.0 software program (Statsoft, Tulsa, USA). 


\section{Results}

A total of 8,046 sand fly specimens from 11 genera and 28 species were collected in the XIR over the course of the study, 5,406 of which were female (67.2\%) and 2,640 of which were male $(32.8 \%)$. In the peridomicile areas, 2,126 (26.4\%) sand fly specimens from 9 genera and 19 species were collected. We observed a significant difference between the number of males and females collected in peridomicile areas $\left(\mathrm{H}_{1.198}=26.62 ; \mathrm{p}=0.000\right)$, with more females $(1,385)$ than males $(741)$ collected. The most commonly sampled species and their relative frequencies within peridomicile areas were Lutzomyia longipalpis (51.08\%), Nyssomyia intermedia (31.79\%) and Micropygomyia goiana (3.01\%). Along the different trail ecotopes, 5,920 sand fly specimens $(73.6 \%$ of total) from 11 genera and 27 species were collected. We also observed a significant difference between the numbers of males and females collected along the trails $\left(\mathrm{F}_{1.36}=\right.$ 28.239; $\mathrm{p}=0.000$ ). The most commonly sampled species along the trail ecotopes were Martinsmyia minasensis (26.7\%), Lutzomyia cavernicola (17.24\%) and Lutzomyia renei $(14.0 \%)$. The highest sand fly abundance was observed along trail $3(52.58 \%)$, followed by trail 4 (34.71\%), whereas only $12.71 \%$ of the total sand flies were collected along the other trails $(\mathrm{p}<0.05)$. An analysis of species richness revealed a significant difference between the number of species collected on the different trails $\left(\mathrm{F}_{3.20}=7.1566 ; \mathrm{p}<0.05\right)$, with trail 2 showing the fewest number of species (15 species). We sampled 20, 20 and 21 different sand fly species on trails 3,4 and 1 , respectively, with no significant differences in species richness between these trails.

Table 1 shows the distribution of the species collected in the peridomicile areas during the studied months. The months with the highest sand fly abundances were November 2008 (36.92\%) and September 2008 (25.77\%), with the other months accounting for $37.31 \%$ of the sand flies collected. We observed a significant difference in abundance $\left(\mathrm{H}_{5.99}=18.44 ; \mathrm{p}=0.002\right)$ and species richness between the different months $\left(\mathrm{H}_{5.99}=29.58 ; \mathrm{p}=0.000\right)$.

Species richness was significantly different between the dry and rainy seasons $\left(\mathrm{H}_{1.99}=4.57 ; \mathrm{p}=0.0325\right)$, and a greater number of sand fly species was collected during the rainy season in peridomicile areas.

Distribution of sand fly species collected along the trails on a month-by-month basis is shown on Table 2 . A significant difference in sand fly abundance was observed between the different months $\left(\mathrm{F}_{5.12}=48.257 ; \mathrm{P}=\right.$ 0.000 ), with the highest abundances being observed in December 2011 (22.9\%) and June 2012 (21.6\%); there was no significant difference in abundance between these two months. However, we observed no significant difference in species richness based on month for the different trails $\left(\mathrm{F}_{5.12}=1.5990 ; \mathrm{p}=0.23381\right)$.
A significant difference in sand fly abundance was observed between the dry and rainy seasons when the collections were performed on the trails, with the rainy season showing the greatest number of sand flies $\left(\mathrm{F}_{1.36}=4.7571\right.$; $\mathrm{p}=0.03579$ ).

Female sand flies were more abundant than males during both the dry and rainy seasons but were more predominant during the rainy season $(\mathrm{F} 1.36=8.7494 ; \mathrm{p}=$ $0.00544)$. However, there was no significant difference in the number of sampled species in terms of males or females based on season (F1.36 $=2.6521 ; \mathrm{p}=0.11214)$.

The results of the multivariate analysis comparing the compositions of the Phlebotominae fauna among the different studied environments (forest, rocky outcrop and transition forest) and seasons (dry and rainy) are shown in Figure 3. The vertical line passing through the $\mathrm{X}$-axis origin shows the difference in the sand fly fauna compositions between the forest area (trails 1 and 2), grouped in the right side of the line, while the rocky outcrop (trail 3) and the transitional region (trail 4) grouped in the left side, show that the sand fly fauna composition in the study area was different. Furthermore, the horizontal line passing through the Y-axis origin highlights the difference in sand fly fauna composition between the rainy (above the line) and dry (bellow the line) seasons.

\section{Discussion}

A number of studies have described the behavior of the Phlebotominae fauna, primarily those of medical importance [27-29]. Sand flies can be commonly found in a variety of natural ecotopes, including tree trunks, animal burrows, dead leaves, and rocky crevices [30-34], as well as in rural and urban environments close to domestic animal shelters and human residences [35-39]. Considering the diversity of ecotopes in which sand flies can be found, sampling from a variety of different environments within a given study area is crucial for fauna studies. In this study, we collected sand flies from several different areas, including peridomicile areas around households as well as trails containing a variety of ecotopes, such as cerrado forests, seasonal deciduous forests, cerrado strictu sensu and transition areas between cerrado and caatinga.

A great variety of genera and species were found in the Imbaúbas native village, corresponding to about 30\% of the total registered species in the state of Minas Gerais [10-14].

Despite the fact that the collections in the peridomicile areas and along the trails were performed during different periods, precluding a statistical comparison between the ecotopes, certain findings were still significant. With respect to species richness, a higher diversity of sand flies was observed in the trails when compared to peridomicile areas. This difference was likely due to the 
Table 1 Sand flies collected by sex and seasons in peridomicile located in Imbaúbas village, Xakriabá Indigenous Reserve, MG, from July 2008 to July 2009

\begin{tabular}{|c|c|c|c|c|c|c|c|c|c|c|c|c|c|c|c|}
\hline \multirow{4}{*}{ Species } & \multicolumn{12}{|c|}{ Sampling months } & & & \\
\hline & \multicolumn{6}{|c|}{ Dry season } & \multicolumn{6}{|c|}{ Rainy season } & \multirow{2}{*}{\multicolumn{3}{|c|}{ Total }} \\
\hline & \multicolumn{2}{|c|}{ Jul-08 } & \multicolumn{2}{|c|}{ Sep-08 } & \multicolumn{2}{|c|}{ Jul-09 } & \multicolumn{2}{|c|}{ Nov-08 } & \multicolumn{2}{|c|}{ Jan-09 } & \multicolumn{2}{|c|}{ Apr-09 } & & & \\
\hline & q & $0^{\pi}$ & $q$ & $0^{\prime \prime}$ & $q$ & $0^{x}$ & q & $0^{x}$ & $q$ & $0^{x}$ & $q$ & $0^{x}$ & १ (\%) & $\sigma^{x}(\%)$ & Total (\%) \\
\hline Brumptomyia avellari & 0 & 1 & 2 & 3 & 1 & 2 & 15 & 14 & 0 & 0 & 1 & 0 & $19(48.7)$ & $20(51.3)$ & $39(1.80)$ \\
\hline Evandromyia lenti & 3 & 4 & 10 & 7 & 1 & 1 & 13 & 6 & 0 & 0 & 1 & 0 & $31(60.7)$ & $20(39.3)$ & $51(2.30)$ \\
\hline Evandromyia cortelezzii & 0 & 0 & 6 & 0 & 0 & 0 & 0 & 3 & 0 & 0 & 1 & 1 & $7(63.6)$ & $4(36.4)$ & $11(0.50)$ \\
\hline Evandromyia cortelezzii complex & 0 & 0 & 0 & 0 & 0 & 0 & 20 & 0 & 2 & 0 & 0 & 0 & $22(100)$ & $0(0)$ & $22(1.00)$ \\
\hline Evandromyia sallesi & 1 & 0 & 1 & 0 & 0 & 0 & 0 & 2 & 0 & 0 & 0 & 0 & $2(50)$ & $2(50)$ & $4(0.10)$ \\
\hline Evandromyia spelunca & 0 & 0 & 0 & 1 & 1 & 0 & 4 & 0 & 0 & 0 & 0 & 0 & $5(80)$ & $1(20)$ & $6(0.20)$ \\
\hline Evandromyia termitophila & 0 & 0 & 1 & 0 & 1 & 3 & 0 & 0 & 0 & 0 & 1 & 0 & $3(50)$ & $3(50)$ & $6(0.20)$ \\
\hline Lutzomyia ischnacantha & 0 & 0 & 6 & 2 & 0 & 0 & 10 & 2 & 0 & 0 & 2 & 3 & $18(72)$ & $7(28)$ & $25(1.10)$ \\
\hline Lutzomyia longipalpis & 6 & 39 & 176 & 60 & 33 & 42 & 260 & 295 & 40 & 54 & 27 & 54 & $542(49.9)$ & $544(50.1)$ & $1086(51)$ \\
\hline Lutzomyia sp.* & 1 & 0 & 0 & 6 & 0 & 0 & 15 & 5 & 0 & 1 & 11 & 2 & $27(65.8)$ & $14(34.2)$ & $41(1.90)$ \\
\hline Lutzomyia renei & 0 & 1 & 14 & 0 & 0 & 0 & 16 & 0 & 1 & 0 & 2 & 0 & $33(97)$ & $1(3)$ & $34(1.60)$ \\
\hline Martinsmyia minasensis & 0 & 0 & 0 & 0 & 0 & 0 & 1 & 0 & 0 & 0 & 0 & 0 & $1(100)$ & $0(0)$ & $1(0.04)$ \\
\hline Micropygomyia capixaba & 0 & 0 & 0 & 0 & 0 & 3 & 0 & 0 & 1 & 0 & 2 & 0 & $3(50)$ & $3(50)$ & $6(0.20)$ \\
\hline Micropygomyia goiana & 0 & 2 & 10 & 2 & 1 & 1 & 24 & 19 & 2 & 0 & 2 & 1 & $39(60.9)$ & $25(39.1)$ & $64(3)$ \\
\hline Micropygomyia peresi & 1 & 0 & 0 & 0 & 1 & 1 & 6 & 1 & 2 & 0 & 2 & 0 & $12(85.7)$ & $2(14.3)$ & $14(0.60)$ \\
\hline Micropygomyia quinquefer & 0 & 0 & 0 & 0 & 0 & 0 & 0 & 0 & 2 & 0 & 0 & 0 & $2(100)$ & $0(0)$ & $2(0.09)$ \\
\hline Migonemyia migonei & 1 & 5 & 1 & 7 & 2 & 1 & 3 & 5 & 1 & 1 & 0 & 0 & $8(29.6)$ & 19 (70.4) & $27(1.20)$ \\
\hline Nyssomyia intermedia & 179 & 15 & 209 & 20 & 87 & 18 & 40 & 4 & 8 & 3 & 82 & 11 & $605(89.4)$ & $71(10.6)$ & $676(32.78)$ \\
\hline Nyssomyia whitmani & 0 & 0 & 2 & 1 & 0 & 0 & 0 & 0 & 0 & 1 & 1 & 0 & $3(60)$ & $2(40)$ & $5(0.20)$ \\
\hline Pintomyia serrana & 0 & 0 & 1 & 0 & 0 & 0 & 2 & 0 & 0 & 0 & 0 & 1 & $3(75)$ & $1(25)$ & $4(0.10)$ \\
\hline Sciopemyia sordellii & 0 & 0 & 0 & 0 & 0 & 0 & 0 & 0 & 0 & 2 & 0 & 0 & $0(0)$ & $2(100)$ & $2(0.09)$ \\
\hline \multirow[t]{2}{*}{ Total (\%) } & $192(74.1)$ & $67(25.9)$ & $439(80.1)$ & 109 (19.9) & $128(64)$ & $72(36)$ & $429(54.6)$ & $356(45.4)$ & $59(48.7)$ & $62(51.3)$ & $138(64.7)$ & $75(35.3)$ & $1385(65.1)$ & 741 (34.9) & $2126(100)$ \\
\hline & \multicolumn{2}{|c|}{259 (12.18) } & \multicolumn{2}{|c|}{$548(25.77)$} & \multicolumn{2}{|c|}{$200(9.43)$} & \multicolumn{2}{|c|}{785 (36.92) } & \multicolumn{2}{|c|}{$121(5.69)$} & \multicolumn{2}{|c|}{$213(10.01)$} & \multicolumn{3}{|c|}{2126} \\
\hline
\end{tabular}


Table 2 Distribution of sandfly species collected on tracks according to sex, sampling months and seasons in Imbaúbas village, Xakriabá Indigenous Reserve, MG

\begin{tabular}{|c|c|c|c|c|c|c|c|c|c|c|c|c|c|c|c|}
\hline \multirow{3}{*}{ Species } & \multicolumn{12}{|c|}{ Sampling months } & \multirow{2}{*}{\multicolumn{3}{|c|}{ Total }} \\
\hline & \multicolumn{2}{|c|}{ Oct-11 } & \multicolumn{2}{|c|}{ Dec-11 } & \multicolumn{2}{|c|}{ Feb-12 } & \multicolumn{2}{|c|}{ Apr-12 } & \multicolumn{2}{|c|}{ Jun-12 } & \multicolumn{2}{|c|}{ Aug-12 } & & & \\
\hline & $q$ & $0^{x}$ & q & $0^{n}$ & q & $0^{x}$ & $q$ & $0^{n}$ & q & $0^{x}$ & $q$ & $0^{x}$ & १ (\%) & $\sigma^{\pi}(\%)$ & Total (\%) \\
\hline Brumptomyia avellari & 1 & 1 & 0 & 0 & 0 & 0 & 1 & 0 & 3 & 1 & 0 & 0 & $5(71.4)$ & $2(28.6)$ & $7(0.1)$ \\
\hline Brumptomyia brumpti & 0 & 0 & 0 & 0 & 0 & 0 & 0 & 0 & 2 & 0 & 0 & 0 & $2(100)$ & $0(0)$ & $2(0.04)$ \\
\hline Evandromyia cortelezzii & 0 & 0 & 4 & 0 & 0 & 0 & 0 & 0 & 0 & 0 & 3 & 0 & $7(100)$ & $0(0)$ & $7(0.1)$ \\
\hline Evandromyia evandroi & 0 & 0 & 0 & 0 & 0 & 0 & 0 & 0 & 7 & 0 & 0 & 0 & $7(100)$ & $0(0)$ & $7(0.1)$ \\
\hline Evandromyia lenti & 6 & 10 & 0 & 7 & 6 & 5 & 4 & 18 & 66 & 25 & 4 & 3 & $86(55.8)$ & $68(44.2)$ & $154(2.61)$ \\
\hline Evandromyia sallesi & & & 1 & 0 & 1 & 0 & 2 & 0 & 0 & 0 & 0 & 0 & 0 & 0 & $4(100)$ \\
\hline Evandromyia sp.* & 0 & 4 & 0 & 0 & 0 & 0 & 0 & 0 & 0 & 0 & 0 & 0 & $0(0)$ & $4(100)$ & $4(0.07)$ \\
\hline Evandromyia spelunca & 0 & 50 & 28 & 43 & 8 & 84 & 16 & 63 & 16 & 51 & 11 & 31 & $79(19.7)$ & $322(80.3)$ & $401(6.82)$ \\
\hline Evandromyia termitophila & 4 & 10 & 0 & 1 & 0 & 0 & 1 & 2 & 0 & 13 & 2 & 3 & $7(19.4)$ & $29(80.6)$ & $36(0.6)$ \\
\hline Lutzomyia cavernicola & 0 & 0 & 2 & 263 & 5 & 49 & 2 & 118 & 2 & 416 & 1 & 180 & $12(1.1)$ & $1026(98.9)$ & $1038(17.52)$ \\
\hline Lutzomyia ischnacantha & 0 & 6 & 28 & 64 & 11 & 40 & 25 & 41 & 58 & 59 & 41 & 10 & $163(42.5)$ & $220(57.50)$ & $383(6.50)$ \\
\hline Lutzomyia longipalpis & 7 & 4 & 0 & 1 & 0 & 2 & 3 & 5 & 29 & 28 & 2 & 1 & $41(50)$ & $41(50)$ & $82(1.40)$ \\
\hline Lutzomyia renei & 13 & 5 & 107 & 28 & 59 & 0 & 85 & 134 & 270 & 0 & 131 & 0 & $665(79.9)$ & $167(20.1)$ & $832(14)$ \\
\hline Lutzomyia sp.* & 0 & 39 & 0 & 0 & 0 & 0 & 0 & 0 & 0 & 0 & 0 & 0 & $0(0)$ & $39(100)$ & $39(0.60)$ \\
\hline Martinsmyia minasensis & 58 & 559 & 150 & 234 & 98 & 341 & 18 & 64 & 6 & 37 & 2 & 0 & $332(21.1)$ & $1235(78.9)$ & $1567(26.62)$ \\
\hline Micropygomyia capixaba & 0 & 0 & 12 & 114 & 0 & 45 & 0 & 48 & 0 & 0 & 2 & 0 & $14(6.3)$ & $207(93.7)$ & $221(3.70)$ \\
\hline Micropygomyia goiana & 1 & 96 & 5 & 29 & 8 & 9 & 22 & 74 & 26 & 45 & 4 & 16 & $66(19.7)$ & $269(80.3)$ & $335(5.70)$ \\
\hline Micropygomyia longipennis & 0 & 8 & 0 & 12 & 0 & 0 & 0 & 0 & 0 & 2 & 0 & 0 & $0(0)$ & $22(100)$ & $22(0.30)$ \\
\hline Micropygomyia peresi & 27 & 37 & 152 & 34 & 7 & 33 & 84 & 57 & 32 & 10 & 12 & 0 & $314(64.7)$ & $171(35.3)$ & $485(8.10)$ \\
\hline Micropygomyia quinquefer & 0 & 0 & 0 & 0 & 0 & 0 & 2 & 0 & 0 & 0 & 0 & 0 & $2(100)$ & $0(0)$ & $2(0.04)$ \\
\hline Micropygomyia schreiberi & 0 & 0 & 21 & 0 & 3 & 0 & 2 & 2 & 4 & 10 & 4 & 35 & $34(41.9)$ & $47(58.1)$ & $81(1.40)$ \\
\hline Micropygomyia sp.* & 0 & 12 & 0 & 0 & 0 & 0 & 0 & 0 & 0 & 1 & 0 & 0 & $0(0)$ & $13(100)$ & $13(0.20)$ \\
\hline Migonemyia migonei & 0 & 2 & 0 & 0 & 0 & 1 & 0 & 0 & 1 & 0 & 0 & 0 & $1(25)$ & $3(75)$ & $4(0.07)$ \\
\hline Nyssomyia intermedia & 1 & 9 & 5 & 6 & 9 & 42 & 14 & 42 & 17 & 39 & 0 & 1 & $46(24.8)$ & $139(75.2)$ & $185(3.20)$ \\
\hline Nyssomyia neivai & 0 & 0 & 0 & 0 & 0 & 0 & 0 & 0 & 0 & 2 & 0 & 0 & $0(0)$ & $2(100)$ & $2(0.04)$ \\
\hline Pintomyia misionensis & 0 & 0 & 0 & 0 & 0 & 0 & 0 & 1 & 0 & 0 & 0 & 0 & $0(0)$ & $1(100)$ & $1(0.02)$ \\
\hline Pintomyia serrana & 0 & 0 & 0 & 0 & 0 & 0 & 0 & 1 & 0 & 0 & 0 & 0 & $0(0)$ & $1(100)$ & $1(0.02)$ \\
\hline Psathyromyia (Foratiniella) sp.* & 0 & 0 & 0 & 0 & 0 & 1 & 0 & 0 & 0 & 0 & 0 & 0 & $0(0)$ & $1(100)$ & $1(0.02)$ \\
\hline
\end{tabular}


Table 2 Distribution of sandfly species collected on tracks according to sex, sampling months and seasons in Imbaúbas village, Xakriabá Indigenous Reserve, MG (Continued)

\begin{tabular}{|c|c|c|c|c|c|c|c|c|c|c|c|c|c|c|c|}
\hline Psychodopygys ayrozai & 0 & 0 & 1 & 0 & 0 & 0 & 0 & 0 & 0 & 0 & 0 & 0 & $1(100)$ & $0(0)$ & $1(0.02)$ \\
\hline Scyopemyia sordellii & 0 & 0 & 0 & 0 & 1 & 0 & 0 & 1 & 0 & 1 & 0 & 0 & $1(33.4)$ & $2(66.6)$ & $3(0.06)$ \\
\hline Total (\%) & $\begin{array}{c}119 \\
(12.3)\end{array}$ & $\begin{array}{c}852 \\
(87.7)\end{array}$ & $\begin{array}{c}516 \\
(38.1)\end{array}$ & $\begin{array}{c}836 \\
(61.9)\end{array}$ & $\begin{array}{c}217 \\
(24.9)\end{array}$ & $\begin{array}{c}652 \\
(75.1)\end{array}$ & $\begin{array}{c}279 \\
(29.3)\end{array}$ & $\begin{array}{c}671 \\
(70.7)\end{array}$ & $\begin{array}{c}539 \\
(42.1)\end{array}$ & $\begin{array}{c}740 \\
(57.9)\end{array}$ & $\begin{array}{c}219 \\
(43.8)\end{array}$ & $\begin{array}{c}280 \\
(56.2)\end{array}$ & $\begin{array}{c}1889 \\
(31.9)\end{array}$ & $\begin{array}{l}4031 \\
(68.1)\end{array}$ & $\begin{array}{l}5920 \\
(100)\end{array}$ \\
\hline & \multicolumn{2}{|c|}{971 (16.4) } & \multicolumn{2}{|c|}{1352 (22.9) } & \multicolumn{2}{|c|}{869 (14.7) } & \multicolumn{2}{|c|}{$950(16.0)$} & \multicolumn{2}{|c|}{1279 (21.6) } & \multicolumn{2}{|c|}{$499(8.4)$} & \multicolumn{3}{|c|}{5920} \\
\hline
\end{tabular}

*The specimens have damaged essential morphological structures. 


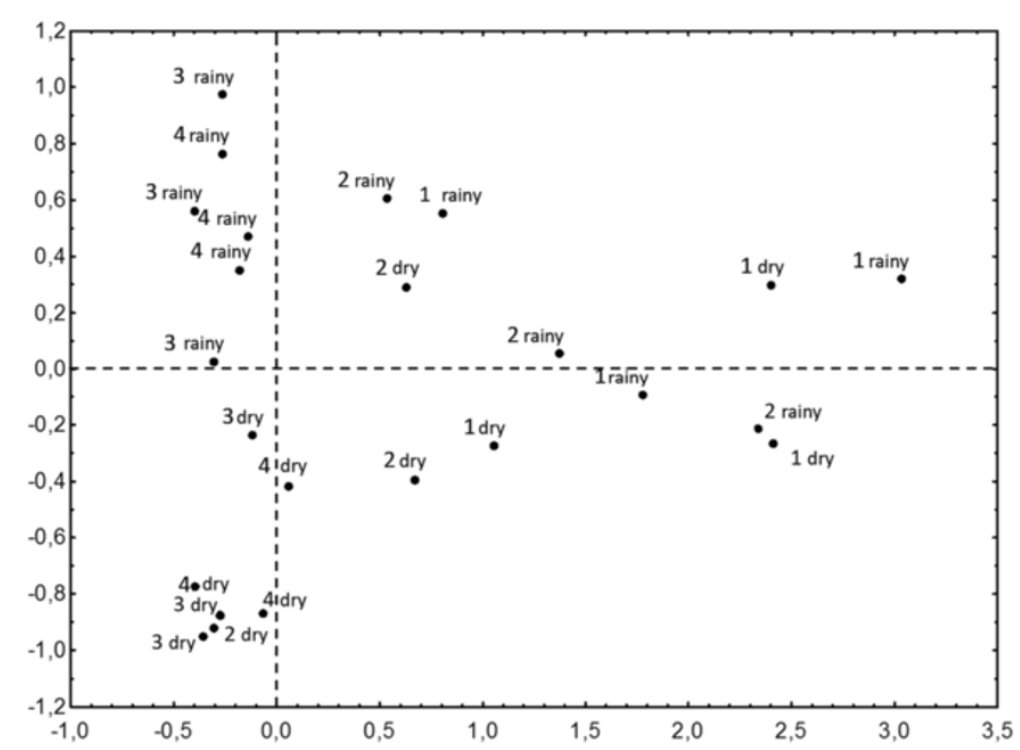

Figure 3 Statistical analysis comparing the sand fly fauna. A multivariate analysis comparing the Phlebotominae fauna between the different studied environments (forest, rocky outcrop, transition forest) and seasons (dry and rainy). Each point corresponds one month of collection in each trail, totaling six points per trail.

diversity of ecotopes found along the trails as well as the preferences of the sand flies for the specific wild animals, domestic animals or humans found in these areas. By definition, peridomicile areas are significantly impacted by human intervention, which likely hinders the adaptation of certain sand fly species to these areas. It is important to note that the peridomicile areas surrounding houses within the XIR possess numerous rural characteristics, such as domestic animals, fruit trees and grain plantations, that provide shelter and food sources for adult sand flies as well as organic matter for the development of immature stages. Therefore, these characteristics may explain the significant number of species (19) found in this ecotope.

In the peridomicile areas, Lu. longipalpis and $N y$. intermedia were the predominant species, which was significantly different from what was observed along the trails, where these species were relatively rare. Importantly, these species are involved in transmission of the $\mathrm{VL}$ and $\mathrm{ACL}$ etiological agents in several endemic areas of Brazil [1,40].

Since the VL transmission cycle began to be elucidated in Brazil in the 1930s, several research groups have demonstrated the ability of Lu. longipalpis to adapt to humanmodified environments as well as its crucial role in the transmission of Leishmania infantum [1]. Therefore, the near constant presence of Lu. longipalpis in peridomicile, where it can feed on domestic and synanthropic hosts of Leishmania, associated with their anthropophily contribute to its vectorial capacity $[41,42]$. As a consequence,
Lu. longipalpis plays an important role in the transmission of VL in peridomicile areas of both rural and urban regions $[41,43,44]$.

Our results agree with previous entomological studies performed in the north of Minas Gerais state. In these studies, $L u$. longipalpis was identified as the predominant species found in peridomicile areas $[45,46]$. Correlations between $\mathrm{Lu}$. longipalpis density and specific conditions in this environment have been noted, and this species is commonly associated with the presence of domestic animals [47-50]. This behavioral trait was also observed in the present study, as we found domestic animals, including chickens, pigs and dogs in the peridomicile areas.

With respect to $N y$. intermedia, most of the specimens were collected in peridomicile areas and few specimens were collected in forest fragments near residences. These results are consistent with the reports of Forattini in the Paulista plateau, state of São Paulo [47,51] and Rangel et al., in the municipality of Mesquita, state of Rio de Janeiro [52]. These authors showed that $N y$. intermedia sensu lato lives in close association with humans as well as domestic and synanthropic animals in a variety of habitats, including peridomicile and forested areas. Epidemiological evidence accumulated over the years suggests that Ny. intermedia sensu lato is the primary vector of the ACL etiological agent in endemic areas of southeastern Brazil [53-57], and the distribution of this species consistently coincides with the distribution of ACL in humans [51,58-61]. Therefore, based on the proven epidemiological importance of $\mathrm{Ny}$. intermedia sensu lato and 
its high population density within peridomicile areas, this species likely plays an important role in the Leishmania transmission cycle in the XIR.

Despite being found in low numbers in the present study, the presence of the species Ev. cortellezii, Ev. sallesi, Ev. termitophila, Migonemyia migonei, Ny. neivai and Ny. whitmani should also be addressed. These species have been found to be naturally infected by Leishmania in Brazil, thus implicating them as potential etiological vectors, and some may be sporadically involved in Leishmania transmission $[40,56,62,63]$.

It is necessary to highlight the presence of Ev. lenti in both the peridomicile and trail areas, despite the small number of collected specimes. In a study performed in Ceará state - Brazil [64], although only a small number of $E v$. lenti individuals were found in peridomicile areas, a large number were found inside the associated households. In the municipality of Jacobina, state of Bahia Brazil, Ev. lenti specimens that were naturally infected with promastigotes were found biting humans, horses and dogs [65]. In contrast with these reports, in a study of Ev. lenti biology involving a population from the state of Minas Gerais, demonstrated that this species does not have anthropophilic habits and is refractory to Leishmania species [66]. However, recently, cases of natural infection with Le. braziliensis by Ev. lenti were reported and verified using molecular biology techniques $[67,68]$. Therefore, the epidemiological role of Ev. lenti must be clarified, which is highlighted by the fact that this species was collected in both peridomicile and forested areas near humans in this study.

Regarding the Phlebotominae fauna collected along the trails, it was observed that trail 3 showed the highest sandfly abundance. During the study period, about $40 \%$ of the collected specimens were captured in this ecotope. Furthermore, a high species richness was observed. This phenomenon was primarily due to the environmental composition of trail 3, which consisted of vertical rocky outcrops that formed craters in the soil where temperature and relative humidity remained relatively stable throughout the day, making it a suitable habitat for the breeding and establishment of a variety of vertebrate species, including small- and medium-sized rodents and bats that can serve as food sources for sand flies.

The presence of $M t$. minasensis was largely confined to trails 3 and 4 and little is known concerning the feeding behaviors and habits of this species. Species of the genera Martinsmyia can be attracted by rodents, as suggested to Mt. gasparviannai in the state of Espírito Santo [69] and Mt. oliveirai in the state of Mato Grosso do Sul [34]. In addition to the high prevalence of $M t$. minasensis along the trails, the regular presence of $M i$. peresi, Mi. goiana, Lu. renei, Lu. cavernicola and Ev. spelunca throughout the year suggests that these species use these wild environments as breeding sites, as specimens of both sexes were routinely collected. For the remaining species that were only sporadically collected, our findings suggest that these trails serve only as temporary shelters [70].

The impact of climatic factors on sand fly populations has been addressed by several authors. According to the literature, temperature, humidity and rainfall can influence sand fly populations in varying ways, depending on the region studied. Rutledge \& Ellenwood [71] suggest that sand fly seasonality is related to rainfall distribution patterns, which affect breeding conditions on the ground. In our study, we observed significant correlations between sand fly abundance and the rainy season along the trails, as well as for species richness and the rainy season in the peridomicile areas. Indeed, significant correlations between season and fluctuations in Phlebotominae populations have been observed in several Brazilian states, including Minas Gerais [46,72], Rio Grande do Norte [73], Mato Grosso [74], Mato Grosso do Sul [75,76], Ceará [41] and Bahia [48].

Even slight variations in certain climatic factors can affect sand fly micro-habitat enough to alter population dynamics, as these insects are very sensitive to desiccation [45]. Therefore, this phenomenon may explain the higher number of sand flies collected along trail 3, which consisted of rocky outcrops that could serve as microhabitat with relatively stable temperature and humidity throughout the year. However, in the forest, transition and peridomicile areas, climatic changes occur more frequently, leading to environmental changes throughout the year. For example, during the driest months, reduced rainfall levels result in drastically reduced vegetation cover (characteristic of seasonal deciduous forests), which may directly affect the sand flies breeding sites.

\section{Conclusion}

In recent decades, significant changes have been occurring in many natural environments, mostly due to human activity. As a result, many insects that transmit disease and various components of parasitic life cycles are beginning to show population dynamics and interactions different from their original descriptions. Therefore, studies involving fauna surveys that also address biological aspects of specific vectors contribute to a better understanding of the dynamic interactive processes between hosts and parasites. This study addressed the sand fly fauna in a significant leishmaniasis endemic area, and these results will enhance our knowledge concerning the number of sand fly species found in this region as well as the distribution of these species across different ecotopes. This knowledge may prove useful for establishing more effective prophylactic measures. 


\section{Abbreviations}

XIR: Xakriabá indigenous reserve; ACL: Cutaneous Leishmaniasis; VL: Visceral Leishmaniasis; FUNAl: National Indian Foundation.

\section{Competing interests}

The authors declare that they have no competing interests.

\section{Authors' contributions}

FDR: designed the study, field work, processed and identified the collected sand flies and wrote the manuscript. PHFS: field work, identified the collected sand flies and reviewed the manuscript; PFQ: designed the study, field work and statistical analysis; IRC: statistical analysis; GBT: field work and processed the collected sand flies; KMSS: field work and processed the collected sand flies; RAB: processed the collected sand flies, conceived and designed the experiments; ESD: conceived and designed the experiments; CMFG: designed the study, financial support for the study and reviewed the manuscript. All authors approved the final version of the manuscript.

\section{Acknowledgments}

The authors thank the inhabitants of the XIR for contributing to this study. Financial support was given by the National Council for Scientific and Technological Development, the Minas Gerais Research Foundation (FAPEMIG) and the Oswaldo Cruz Foundation (FIOCRUZ).

\section{Author details}

${ }^{1}$ Grupo de Estudos em Leishmanioses, Centro de Pesquisas René Rachou, Fundação Oswaldo Cruz, Av. Augusto de Lima, 1715 Barro Preto, CEP 30190-002 Belo Horizonte, Minas Gerais, Brazil. 'Laboratório de Ecologia e Sistemática de Abelhas, Sala 245, Bloco E2 Instituto de Ciências Biológicas, Universidade Federal de Minas Gerais Avenida Presidente Antônio Carlos, 6627 Caixa Postal 486, CEP 31270-901 Belo Horizonte, Minas Gerais, Brazil. ${ }^{3}$ Departamento de Ciências Biológicas, Universidade Federal dos Vales do Jequitinhonha e Mucuri - Campus JK, BR 367, Alto da Jacuba, CEP 39100-000 Diamantina, MG, Brazil.

Received: 11 March 2014 Accepted: 6 May 2014

Published: 12 May 2014

\section{References}

1. Rangel EF, Lainson R: Ecologia das leishmanioses. In Flebotomíneos do Brasil. Edited by Rangel EF, Lainson R. Rio de Janeiro: Fiocruz; 2003:368.

2. Forattini OP: Entomologia Médica IV. In Psychodidae. Phlebotominae, Leishmaniose e Bartonelose, Volume VIII. Edited by Blucher E. São Paulo: Ltda; 1973:658.

3. Christensen $\mathrm{H}$, Herrer A: Susceptability of sandflies (Diptera:Psychodidae), to trypanosomatidae from two-toed sloths (Edentata: Bradypodidae). J Med Entomol 1979, 16:424-427.

4. Warburg A: Entomopathogens of phlebotomine sand flies: laboratory experiments and natural infections. J Inv Pathol 1991, 58:1889-202.

5. Shaw JJ: Endotrypanum, a unique intraerythrocytic flagellate of New World tree sloths. An evolutionary link or an evolutionary backwater? Ciência e Cultura 1992, 44:107-116.

6. Dujardin JP, Bermúdez H, Gianella A, Cardozo L, Ramos E, Saravia R, Quiroz K, Forgues G, Carazas R, Hervas D, Chavez T, Machane M, Martínez E, Torrez M: Uso de marcadores geneticos en la vigilancia entomologica de la enfermedad de Chagas. In La Enfermedad de Chagas en Bolivia - Conocimientos científicos al inicio del Programa de Control (1998-2002). Edited by Cassab JA, Noireau F, Guillen G. Ministerio de Salud y Prevision social: OMS/OPS, IRD and IBBA; 1999:157-169.

7. Sherlock IA: A importância dos flebotomíneos. In Flebotomíneos do Brazil. Edited by Rangel EF, Lainson R. Rio de Janeiro: Fiocruz; 2003:15-21.

8. Galati EAB: Classificação de Phlebotominae. In Flebotomíneos do Brazil. Edited by Rangel EF, Lainson R. Rio de Janeiro: Fiocruz; 2003:23-53.

9. Ready P: Biology of Phlebotomine Sand Flies as Vectors of Disease Agents. Ann Rev Entomology 2013, 58:227-250.

10. Andrade AJ, Dantas-Torres F: Phlebotomine sand flies (Diptera: Psychodidae) of the state of Minas Gerais, Brazil. Neotrop Entomol 2010, 39:115-123.

11. Carvalho GML, Brazil RP, Sanguinette CC, Andrade-Filho JD: Description of Evandromyia spelunca, a new phlebotomine species of the cortelezzii complex from a cave in Minas Gerais state, Brazil (Diptera: Psychodidae: Phlebotominae). Parasit Vectors 2011, 4:158

12. Barata RA, Meira PCLS, Carvalho GML: Lutzomyia diamantinensis sp. nov., a new phlebotomine species (Diptera: Psychodidae) from a quartzite cave in Diamantina, state of Minas Gerais, Brazil. Mem Inst Osw Cruz 2012, 107:1006-1010.

13. Andrade AJ, Galati EAB: A new species of Evandromyia (Diptera: Psychodidae: Phlebotominae) from Minas Gerais State, Brazil. Jour Med Entomol 2012, 49:445-450.

14. Carvalho GML, Brazil RP, Ramos MCNF, Meira PCLS, Zenóbio APLA, Botelho HA, Sanguinette CC, Saraiva L, Andrade Filho JD: Ecological Aspects of Phlebotomine Sandflies (Diptera: Psychodidae) from a Cave of the Speleological Province of Bambuí, Brazil. PLoS One 2013, 8(10):e77158.

15. Carneri I, Nutels N, Miranda JN: Epidemia de leishmaniose tegumentar entre índios Wurá do Parque Nacional do Xingu (Estado de Mato Grosso, Brasil). Rev Inst Med Trop Sao Paulo 1963, 5:271-272.

16. Castellón EG, Guerra JO, Costa YC: A leishmaniose visceral (calazar) no Estado de Roraima. In Homem, Ambiente e Ecologia no Estado de Roraima. Manaus: Instituto Nacional de Pesquisas da Amazônia; 1998:157-179.

17. Guerra JAO, Barros MLB, Fé NF, Guerra MVE, Castellon E, Paes MG, Sherlock A: Leishmaniose visceral entre índios no Estado de Roraima, Brasil. Aspectos clínico-epidemiológicos de casos observados no período de 1989 a 1993. Rev Soc Bras Med Trop 2004, 37:305-311.

18. Benedetti MSG, Gomes W, Oliveira AS, Asato MS: Aspectos epidemiológicos da leishmaniose visceral em Roraima no período de 1989 a 2008 [abstract]. In Proceedings of the XLV Congresso da Sociedade Brasileira de Medicina Tropical, Recife 2009, 270

19. Moreno EC, Quaresma P, Melo LA, Madeira F, Botelho H, Dias ES, Diniz J, Vasconcelos MS, Gontijo CMF, Melo MN: Prevalência da leishmaniose tegumentar americana na reserva indígena Xacriabá. Recife: Minas Gerais. In Proceedings of the XLV Congresso da Sociedade Brasileira de Medicina Tropical; 2009:361

20. Maciel GBML, Missawa NA: Fauna flebotomínica (Diptera: Psychodidae) em aldeias indígenas do Estado de Mato Grosso. Rev Soc Bras Med Trop 2009, 42:597-602.

21. Nascimento JC, Paiva BR, Malafronte RS, Fernandes WD, Galati EAB: Natural infection of phlebotomines (Diptera: Psychodidae) in a visceral leishmaniasis focus in Mato Grosso do Sul, Brazil. Rev Inst Med Trop 2007 49(2):119-122.

22. Quaresma PF, Rêgo FD, Botelho HA, da Silva SR, Moura-Junior AJ, Teixeira-Neto RG, Madeira FM, Canvalho MB, Paglia AP, Melo MN, Gontijo CMF: Wild, synanthropic and domestic hosts of Leishmania in an endemic area of cutaneous leishmaniasis in Minas Gerais State, Brazil. Trans $R$ Soc Trop Med Hyg 2011, 105:579-585.

23. Pugedo H, Barata RA, França-Silva JC, Silva JC, Dias ES: HP: um modelo aprimorado de armadilha luminosa de sucção para a captura de pequenos insetos. Rev Soc Bras Med Trop 2005, 38:70-72.

24. Langeron M: Précis de microscopie. Paris: Masson et Cie, Libraires de L'Académie de Medicine Saint-Germain; 1949.

25. Marcondes CB: A proposal of generic and subgeneric abbreviations of phlebotomines sandflies (Diptera: Psychodidae: Phlebotominae) of the world. Entomol News 2007, 118:351-356.

26. Instituto Nacional de Meteorologia: Normais Climatológicas (1961-1990). Brasília: Instituto Nacional de Meteorologia; 2012.

27. Andrade Filho JD, Carneiro APS, Lima MLN, Santiago RM, Gama MA Santos CA, Falcão AL, Brazil RP: Flebotomíneos de Timóteo, Estado de Minas Gerais, Brasil (Diptera: Psychodidae). Cad Saúde Pública 1997 13:767-770.

28. Mayo RC, Casanova C, Mascarini LM, Pignatti MG, Rangel O, Galati EAB, Warderley DMV, Corrêa FMA: Flebotomíneos (Diptera, Psychodidae) de área de transmissão de leishmaniose tegumentar americana, no município de Itupeva, região sudeste do Estado de São Paulo. Rev Soc Bras Med Trop 1998, 31:339-345.

29. Rebêlo JMM: Frequência horária e sazonalidade de Lutzomyia longipalpis (Diptera: Psychodidae: Phlebotominae) na ilha de São Luís, Maranhão, Brasil. Cad Saúde Pública 2001, 17:221-227.

30. Arias JR, Freitas RA: On the vectors of cutaneous leishmaniasis in the Central Amazon of Brazil. 3. Phlebotomine sand fly stratification in a terra firme florest. Acta Amazon 1982, 12:599-608.

31. Aguiar GM, Schuback PA, Vilela ML, Azevedo ACR: Aspectos da ecologia dos flebótomos do Parque Nacional da Serra dos Órgãos, Rio de Janeiro. 
II - Distribuição vertical (Diptera, Psychodidae, Phlebotominae). Mem Inst Oswaldo Cruz 1985, 80:187-194.

32. Alexander B, Ferro C, Young DG, Morales A, Tesh RB: Ecology of phlebotomine sand flies (Diptera: Psychodidae) in a focus of Leishmania (Viannia) braziliensis in Northern Colombia. Mem Inst Oswaldo Cruz 1992, 87:387-395.

33. Azevedo ACR, Luz SLB, Vilela ML, Rangel EF: Studies on the sandfly fauna of Samuel ecological station, Porto Velho municipality, Rondônia state, Brazil. Mem Inst Oswaldo Cruz 1993, 88:509-512.

34. Galati EAB, Nunes VL, Boggiani PC, Dorval MEC, Cristaldo G, Rocha HC, Oshiro ET, Damasceno-Júnior GA: Phlebotomines (Diptera: Psychodidae) in forested areas of the Serra da Bodoquena, state of Mato Grosso do Sul, Brazil. Mem Inst Oswaldo Cruz 2006, 101:175-193.

35. Ryan L, Brazil RP: Leishmania infections in Lutzomyia longipalpis (Diptera: Psychodidae) on the Island of Sao Luis, Maranhão State, Brazil. Mem Inst Oswaldo Cruz 1984, 79:383-384.

36. Dourado MIC, Noronha CV, Alcântara N, Ichihara MY, Loureiro S: Epidemiologia da leishmaniose tegumentar americana e suas relações com a lavoura e o garimpo, em localidade do Estado da Bahia (Brasil). Rev Saúde Publ 1989, 23:2-8.

37. Santos TG, de Mello Gaia MC, Brazil RP: Attraction of sand flies (Diptera: Psychodidae) to light traps in rural áreas of Minas Gerais state, Brazil. J Am Mosa Control Assoc 2003, 19:74-78.

38. Brazil RP, Passos WL, Fuzari AA, Falcão AL, Andrade Filho JD: The peridomiciliar sand fly fauna (Diptera: Psychodidae) in áreas of cutaneous leishmaniasis in Além Paraíba, Minas Gerais, Brazil. J Vector Ecol 2006, 31:418-420.

39. Michalsky EM, França-Silva JC, Barata RA, Silva FOL, Loureiro AM, Fortes-Dias CL, Dias ES: Phlebotominae distribution in Janaúba, an area of transmission for visceral leishmaniasis in Brazil. Mem Inst Oswaldo Cruz 2009, 104:56-61.

40. Andrade Filho JD, Galati EAB, Falcão AL: Nyssomyia intermedia (Lutz \& Neiva, 1912) and Nyssomyia neivai (Pinto, 1926) (Diptera: Psychodidae: Phlebotominae) geographical distribution and epidemiological importance. Mem Inst Oswaldo Cruz 2007, 102:481-487.

41. Deane LM: Leishmaniose visceral no Brasil. Estudos sobre reservatórios e transmissores realizados no Estado do Ceará. In PhD Thesis. São Paulo: Faculdade de Medicina Universidade de São Paulo; 1956:162.

42. Killick-Kendrick R: Phlebotomine vectors of leishmaniasis: a review. Med Vet Entomol 1990, 4:1-24.

43. Lainson R, Shaw Jj: The role of animals in the epidemiology of South American leishmaniasis. In Biology of the Kinetoplastida, Volume 2. Edited by Lumsden WHR, Evans DA. London and New York: Academic Press; 1979:1-116.

44. Lainson R, Shaw JJ, New World leishmaniasis: The Neotropical Leishmania species. In Topley and Wilson's Microbiology and Microbial Infections Volume 5. 9th edition. Edited by Mahy BWJ, Collier L, Balows A, Sussman M. London: Hodder Education Publishers; 1998:241-266.

45. Dias ES, França-Silva JC, Silva JC, Monteiro EM, Kenia MP, Gonçalves CM, Barata RA: Flebotomíneos (Diptera: Psychodidae) de um foco de leishmaniose tegumentar no estado de Minas Gerais. Rev Soc Bras Med Trop 2007, 40:49-52.

46. Monteiro EM, da França Silva JC, Costa RT, Costa DC, Barata RA, Paula EV, Machado-Coelho GLL, Rocha MF, Fortes-Dias CL, Dias ES: Leishmaniose visceral: estudo de flebotomíneos e infecção canina em Montes Claros, Minas Gerais. Rev Soc Bras Med Trop 2005, 38:147-152.

47. Forattini OP: Novas observações sobre a biologia de flebótomos em condições naturais (Diptera:Psychodidae). Arch Hyg Saúde Publ 1960, 25:209-215.

48. Sherlock IA, Guitton N: Observações sobre Calazar em Jacobina, Bahia III - Alguns dados sobre o Phlebotomus longipalpis, o principal transmissor. Rev Bras Malariol Doen Trop 1969, 21:541-548.

49. Quinnell RJ, Dye C: Correlates of the peridomestic abundance of Lutzomyia longipalpis (Diptera: Psychodidae) in Amazonian Brazil. Med Vet Entomol 1994, 8:219-224.

50. Camargo-Neves VLF, Rodas LAC, Poletto DW, Lage LC, Spinola RMF, Cruz OG: Utilização de ferramentas de análise espacial na vigilância epidemiológica de leishmaniose visceral americana-Araçatuba, São Paulo, Brasil. Cad Saúde Pública 2001, 17:1263-1267.

51. Forattini OP: Nota sobre criadouros naturais de flebótomos em dependências peridomiciliares, no Estado de São Paulo. Ara Fac Hig Saude Pública 1953, 7:158-167.
52. Rangel EF, Meneses CRV, Cupolillo E, Azevedo ACR, Costa WA, Costa SM: Aspectos da ecologia de Lutzomyia intermedia (Lutz \& Neiva, 1912) e a fauna flebotomínica (Diptera: Psychodidae) em área de transmissão da Leishmania (V) braziliensis no Rio de Janeiro. Rev Soc Bras Med Trop 1999, 32:115.

53. Forattini OP, Santos MR: Nota sobre infecção natural de Phlebotomus intermedius Lutz \& Neiva, 1912, por formas em leptomonas, em foco de leishmaniose tegumentar americana. Arch Hyg Saúde Publ 1952, 17:171-174.

54. Forattini OP, Pattoli DBG, Rabello EX, Ferreira AO: Infecção natural de flebotomíneos em foco enzoótico de leishmaniose tegumentar no estado de São Paulo, Brasil. Rev Saúde Públ 1972, 6:431-433.

55. Casanova C, Mayo RC, Rangel O, Mascarini LM, Pignatti MG, Galati EAB, Gomes AC: Natural Lutzomyia intermedia (Lutz \& Neiva) infection in the Valley of the Mogi Guaçú River, State of São Paulo, Brazil. Bol Dir Malariol San Amb 1995, 35:77-84.

56. Saraiva L, Carvalho GM, Gontijo CM, Quaresma PF, Lima AC, Falcão AL, Andrade Filho JD: Natural infection of Lutzomyia neivai and Lutzomyia sallesi (Diptera: Psychodidae) by Leishmania infantum chagasi in Brazil. J Med Entomol 2009, 46:1159-1163.

57. Rangel EF, Lainson R: Proven and putative vectors of American cutaneous leishmaniasis in Brazil: aspects of their biology and vectorial competence. Mem Inst Oswaldo Cruz 2009, 104:937-954.

58. Forattini OP: Observações feitas sobre a transmissão da Leishmaniose Tegumentar no Estado de São Paulo, Brasil. Rev Saude Publica 1976, 10:31-43.

59. Gomes AC, Santos JLF, Galati EAB: Ecological aspects of American cutaneous leishmaniasis. 4. Observations on the endophilic behaviour of the Sandfly and the vectorial role of Psychodopigus intermedius in the Ribeira Valley region of the São Paulo State, Brazil. Rev Saude Publica 1986, 20:280-287.

60. Rangel EF, Souza NA, Wermelinger ED, Azevedo ACR, Barbosa AF, Andrade CA: Flebótomos de Vargem Grande, Foco de leishmaniose tegumentar não Estado do Rio de Janeiro. Mem Inst Oswaldo Cruz 1986, 81:347-349.

61. Rangel EF, Azevedo ACR, Andrade CA, Souza NA: Estudos Wermelinger e D. sobre a fauna de flebotomíneos (Diptera: Psychodidae) em um foco de Leishmaniose cutânea em Mesquita, Rio de Janeiro. Mem Inst Oswaldo Cruz 1990, 85:39-45.

62. Pita-Pereira D, Alves CR, Souza MB, Brazil RP, Bertho AL, Barbosa AF, Britto CC: Identifications of naturally infected Lutzomyia intermedia and Lutzomyia migonei with Leishmania (Viannia) braziliensis in Rio de Janeiro (Brazil) revealed by a PCR multiplex non-isotopic hybridization assay. Acta Trop 2005, 99:905-913.

63. Carvalho GML, Andrade Filho JD, Falcão AL, Rocha ACVM, Gontijo CMF: Naturally infected Lutzomyia sandflies and the transmission of leishmaniasis in an endemic area of Brazil. Vector Borne Zoonotic Dis 2008, 8:407-414

64. Deane LM, Deane MP: Observações sobre abrigos e criadouros de flebótomos no noroeste do Estado do Ceará. Rev Bras Malar Doen Trop 1957, 9:225-246.

65. Sherlock IA: Sobre o "Phlebotomus lenti" Mangabeira, 1936 (Diptera: Pschodidae). Rev Bras Biol 1957, 17:77-88.

66. Brazil RP, Carneiro VL, Andrade Filho JD, Alves JCM, Falcão AL: Biology of Lutzomyia lenti (Mangabeira) (Diptera: Psychodidae). An Soc Entomol Brasil 1997, 26:191-193.

67. Margonari C, Soares RP, Andrade-Filho JD: Phlebotomine sandflies (Diptera: Psychodidae) and Leishmania infection in Gafanhoto Park, Divinópolis, Brazil. Journal Med Entomol 2010, 47:1212-1219.

68. Paiva BR, Oliveira AG, Dorval MEMC, Galati EAB, Malafronte RS: Species-specific identification of Leishmania in naturally infected sand flies captured in Mato Grosso do Sul State, Brazil. Acta Tropical 2010, 115:126-130.

69. Falqueto A, Grimaldi-Júnior G, Sessa PA, Varejão JBM, Deane LM: Lutzomyia gasparviannai Martins, Godoy \& Silva, 1962, probable vector of Leishmania mexicana ssp. in Viana municipality, Espírito Santo State, Brazil. Mem Inst Oswaldo Cruz 1985, 80:497-502.

70. Galati EAB, Nunes VLB, Rego EA Jr, Oshiro ET, Chang MR: Estudo de flebotomíneos (Diptera, Psychodidae) em foco de leishmaniose visceral no estado de Mato Grosso do Sul, Brasil. Rev Saude Publica 1997, 31:378-390

71. Rutledge LC, Ellenwood DA: Production of plebotomine sandflies on the open forest floor in Panama: The Species. Envir Entomol 1975, 4:71-77. 
72. Barata RA, França- Silva JC, Fortes-Dias CL, Costa RT, Silva JC, Vieira EP, Prata A, Michalsky EM, Dias ES: Phlebotomines sand flies in Porteirinha, an endemic area of American visceral leishmaniasis in the state of Minas Gerais, Brazil. Mem Inst Oswaldo Cruz 2004, 99:481-487.

73. Ximenes MFFM, Souza MF, Castellon EG: Density of sand flies (Diptera: Psychodidae) in domestic and wild animal shelters in an area of visceral leishmaniasis in the state of Rio Grande do Norte, Brazil. Mem Inst Oswaldo Cruz 1999, 94:427-432.

74. Missawa NA, Dias ES: Phlebotomine sand flies (Diptera: Psychodidae) in the municipality of Várzea Grande: an area of transmission of visceral leishmaniasis in the state of Mato Grosso, Brazil. Mem Inst Oswaldo Cruz 2007, 102:913-918.

75. Silva EA, Andreotti R, Honer MR: Comportamento de Lutzomyia longipalpis, vetor principal da leishmaniose visceral americana, em Campo Grande, Estado do Mato Grosso do Sul. Rev Soc Bras Med Trop 2007, 40:420-425.

76. Oliveira AG, Galati EAB, Fernandes CE, Dorval MEC, Brazil RP: Seasonal variation of Lutzomyia longipalpis (Lutz \& Neiva, 1912) (Diptera: Psychodidae: Phlebotominae) in endemic area of visceral leishmaniasis, Campo Grande, state of Mato Grosso do Sul, Brazil. Acta Trop 2008, 105:55-61.

doi:10.1186/1756-3305-7-220

Cite this article as: Rêgo et al:: Ecological aspects of the Phlebotominae fauna (Diptera: Psychodidae) in the Xakriabá Indigenous Reserve, Brazil. Parasites \& Vectors 2014 7:220.

\section{Submit your next manuscript to BioMed Central and take full advantage of:}

- Convenient online submission

- Thorough peer review

- No space constraints or color figure charges

- Immediate publication on acceptance

- Inclusion in PubMed, CAS, Scopus and Google Scholar

- Research which is freely available for redistribution 